\title{
The Use of Dictionaries in the Light of Language Teaching Methods*
}

Refilwe M. Ramagoshi, Department of African Languages, University of Pretoria, Pretoria, Republic of South Africa (refilwe.ramagoshi@up.ac.za)

\begin{abstract}
This article takes a critical look at the role played by second language teaching methods used in teaching African languages as first languages. The traditional method of teaching, used before 1984, encouraged rote learning and teacher-centred lessons. This did not foster the use of dictionaries and, if they were used, the lack of a dictionary culture made their use ineffective. Teachers should be well versed in the functional approach, introduced in 1984, to ensure a smooth transition to Outcomes Based Eductation (OBE). Although its inception since 1994 offers a greater scope for using dictionaries, teachers are still unsure about how the syllabi should be implemented. This, together with the lack of a dictionary culture, results in an inadequate and ineffective dictionary use. Some suggestions are made how this situation could be rectified.
\end{abstract}

Keywords: AFRICAN LANGUAGES, FIRST AND SECOND LANGUAGE TEACHING, TRADITIONAL EDUCATIONAL METHOD, ROTE LEARNING, FUNCTIONAL EDUCATIONAL APPROACH, OUTCOMES BASED EDUCATION, INTERPRETATION OF SYLLABI, AVAILABILITY OF DICTIONARIES, DICTIONARY USAGE, DICTIONARY CULTURE

Opsomming: Die gebruik van woordeboeke in die lig van taalonderrigmetodes. Hierdie artikel werp ' $n$ kritiese blik op die rol wat tweedetaalonderrigmetodes speel by die onderrig van Afrikatale as eerste tale. Die tradisionele metode van onderrig wat voor 1984 gebruik is, het meganiese leer en onderwysergesentreerde lesse aangemoedig. Dit het nie die gebruik van woordeboeke bevorder nie, en, indien hulle gebruik is, het die gebrek aan 'n woordeboekkultuur hul gebruik oneffektief gemaak. Onderwysers moet goed onderleg wees in die funksionele benadering wat in 1984 ingevoer is, om 'n vlot oorgang na Uitkomsgebaseerde Onderrig (UGO) te verseker. Alhoewel die instelling daarvan sedert 1994 'n groter geleentheid vir die gebruik van woordeboeke gebied het, is onderwysers steeds onseker hoe uitvoering aan die sillabusse gegee moet word. Dit, saam met 'n gebrek aan 'n woordeboekkultuur, het 'n ontoereikende en oneffektiewe woordeboekgebruik tot gevolg. 'n Aantal voorstelle word gemaak hoe hierdie situasie verbeter kan word.

Sleutelwoorde: AFRIKATALE, EERSTE- EN TWEEDETAALONDERRIG, TRADISIONELE ONDERRIGMETODE, MEGANIESE LEER, FUNKSIONELE ONDERRIGBENADERING, UITKOMSGEBASEERDE ONDERRIG, INTERPRETASIE VAN SILLABUSSE, BESKIKBAARHEID VAN WOORDEBOEKE, WOORDEBOEKGEBRUIK, WOORDEBOEKKULTUUR

* This article is a revised version of a paper read at the Seminar on Learners' Dictionaries presented by the African Association for Lexicography at the University of Pretoria, Pretoria, Republic of South Africa, 11-12 November 2002.

Lexikos 14 (AFRILEX-reeks/series 14: 2004): 253-263 


\section{Introduction}

The high Matriculation failure rate among Black students is blamed on the fact that the majority of learners, teachers and parents find it difficult to communicate, read or write in English. In the Sunday Times, 30th January 2000, page 2, John Burmeister, National Director: The Molteno Project, states that Matriculation results could be improved by "accelerating the acquisition of competence in English - it being the popular choice of medium".

This addresses the symptoms, not the cause. At the then College of Continuing Training in Soshanguve, which closed down in 1994, it was found that teachers who came to the in-service training, of which the main aim was the improvement of their teaching skills, struggled not only with the methods of teaching an African language, but also with the content of different aspects of grammar and literature, because they could not interpret the syllabi.

The causes for this situation in language education and its impact on a dictionary culture will be dealt with in the following discussion.

\section{Three Phases in Education}

In South Africa, three phases of education can be distinguished, as shown in the following diagram:

\section{PHASE ONE \\ Traditional \\ Method or \\ Rote Learning}

\author{
PHASE TWO \\ Functional or \\ Communicative \\ Approach
}

\author{
PHASE THREE \\ Outcomes Based \\ Education
}

Prior to 1984, most African language teachers used the audio-lingualism theory, which encouraged the drill method, repetition and habit formation, resulting in no distinction between first and second language teaching.

If the first language were used as the language of learning in Grades 0-7 this, at least, would serve as a bridge before acquiring a second language. As a result, at present, both teachers and learners are struggling to learn. Sand and Forthering (1999: 42) suggest that a learner should at least continue with mother-tongue literacy while learning another language although problems might be caused by time constraints. On the same note, Afolayan (1999: 1) states: "Colonial experience has made Africa the continent where the child's mother-tongue is alienated within the educational system."

A teacher not well versed in using a first language approach tends to resort to drill work and rote learning. He/she teaches what he/she remembers from being a learner, sometimes without a clear understanding of the subject matter. This turns into a vicious circle as the teacher literally forces learners to rote learn what he/she was also forced to rote learn by his/her previous teachers. Sand and Forthering (1999: 47) reinforce this observation when they say: 
"Learning to read and write in a language you don't know is a very slow and difficult thing to do."

Gravett (2001: 17) distinguishes between rote learning which does not require active thinking, and meaningful learning which entails an understanding of what is being learnt. Instead of proceeding from the known to the unknown, most teachers do not take into consideration what learners already know from home before coming to school. Ausubel (19782: 163-164) expresses this notion as follows:

Existing cognitive structure ... is the principal factor influencing meaningful learning and retention ... Logically meaningful material is always, and can only be, learned in relation to a previously learned background of relevant concepts, principles, and information ... It is evident ... that the substantive and organizational properties of this background crucially affect both the accuracy and the clarity of these emerging new meanings and their immediate and long-term retrievability.

Construction of an integrated knowledge is important and should be linked to something familiar, as the basis of meaningful learning. It is important that learners should first recognise that the new knowledge relates to what they already know.

Teachers assume they have to start from the beginning when teaching learners. For example, in a lesson on qualificatives, the teacher will make the learners repeat sentences that indicate colours. Yet learners come to school already familiar with colours as they have clothes or toys of different colours. Lessons then become teacher-centred and formulaic in nature as learners are forced to drill the examples as given by teachers. Goodman (1986: 7) summarises it well when he states: "Many school traditions seem to have actually hindered language development. In our zeal to make it easy, we've made it hard."

In 1984, the Department of Education introduced the functional or the communicative approach in first language teaching. By functional approach is meant a method where the living language forms the basis for the study of linguistic phenomena. It does not permit unnatural forced language usage even though the language may be grammatically correct. Leading questions play an important role. The teacher exposes learners to a specific grammatical form and helps them discover the relevant linguistic rules. Learners are lead from what they already know to the unknown - the important point here is that this new knowledge and insight are acquired by means of discovery (Malimabe 1997: 3435).

Each province or region sent only one representative for a specific African language to the Department of Education. On arriving back at school, the representative was expected to report back to all first language teachers and duplicate handouts on the functional approach for each teacher at the inspector's offices. This did not happen. Thus only a few teachers were familiar with the system. 
Another problem this educational approach faced was resistance to change - teachers just seemed to be too comfortable in their traditional method of teaching. This same attitude can also be seen with the introduction of the Outcomes Based Education (OBE) or Curriculum 2005, the new educational system envisaged after the 1994 elections.

OBE is a system built around the process and the outcomes, or the results of learning. According to the White Paper of October 1997, it represents a teaching approach that moves away from the mere gathering of knowledge to an integrated approach, by focusing on the application of knowledge, skills and values. Rote learning has to make way for self-led engagement. This will improve competency as well as values, attitudes or orientations that would benefit learners after leaving school or completing training.

This approach will ensure life-long learning and will benefit the young and the old who left school without acquiring certificates or who have never studied formally but have some sort of experience and skill.

OBE, however, frustrated many teachers due to the difficult terminology used. Teachers were told to forget about differences between aims and objectives of a lesson and concentrate on the term specific outcomes without first being taught the differences between the three terms. Teachers who had never attended courses on the functional approach, encountered more difficulties as they only knew the traditional method. Those who passed through the second phase had an easier transition.

Marambana's research, conducted in 1987, indicated that there were 20000 teachers without certificates. Pressure was put on teachers, some of whom had only completed Matriculation, some the Junior Certificate (J.C.) and some the Primary Teacher's Course (P.T.C.), to improve their qualifications through distance education - hence the birth of the Vista University Distance Education Campus (VUDEC). Some of these teachers taught (especially African languages) because they could not find other work or present the subjects they favoured. Others taught African languages because they were mother-tongue speakers.

However, even certificated teachers who came to the in-service training, had problems with teaching approaches. Snyman et al. (1996: 152), indicated that shortcomings in the curriculum for teacher training were due to the fact that

- $\quad 90 \%$ of the time was spent on theories of grammar or literature, and the history of languages, and

- only $10 \%$ of the time was spent on different skills or methods of teaching grammar and literature.

\subsection{Problems Caused by Rote Learning}

Examples of these can be given from the writing of essays, the testing of comprehension and the teaching of poetry. 


\section{(a) Writing essays}

Learners are often given a full-fledged essay to write without having been taught pre-essay-writing exercises. For example: the use of stylistic devices like long and short sentences for creating a certain atmosphere should be explained to learners.

Another example is that of encouraging learners to employ the five senses, e.g. touching, smelling, seeing, hearing and tasting in developing writing techniques that force learners to use certain parts of speech, idioms, proverbs, ideophones, etc. These aspects of grammar are still taught in isolation and not in context. When marking essays, teachers often just indicate incorrect words without substituting the correct word or encouraging learners to look up the right word in the dictionary (Malimabe 1990: 72). Teachers also used to give learners model essays written by themselves - a procedure which does not encourage creativity and initiative on the learner's part.

\section{(b) Testing comprehension}

Some teachers are unable to identify the keywords in a sentence, the keysentences in a paragraph and the main idea of a passage. They are also unable to explain the meaning of words or use idiomatic expressions in context. This inability of some teachers to summarise, paraphrase or explain is a major problem in the teaching of African languages. For example, in an examination learners were asked to summarise the contents of M. Kgasi's poem "Sefikantswe" (tombstone or statue) in their own words. The learners performed poorly, for, even though they were familiar with the words 'tombstone' or 'statue', they did not know the meaning of the word sefikantswe in Tswana. The word was misinterpreted as follows: se- + -fika + -ntswe.

$$
\begin{array}{ll}
\text { se- } & =\text { class prefix } \\
\text { fika } & =\text { Zulu verbal stem meaning "to arrive" } \\
- \text { ntswe } & =\text { Tswana word meaning "voice" }
\end{array}
$$

As a result the content of the poem as given in their own words did not make sense at all.

This same problem of misinterpretation is also found in Afrikaans. Mother-tongue speakers, who teach second language speakers, tend to neglect the teaching of simple everyday terminology. For example, learners misinterpreted the following topics in essay writing:

'n Nare droom (An Unpleasant Dream)

In the Sotho languages, nare is a buffalo and is spelt the same way as the Afrikaans word nare (unpleasant). So learners confused these two words and wrote: ' $n$ Groot nare het my gejaag, en ek het gehardloop en gehardloop. (A big buffalo chased me, and I ran, and ran.) 


\section{Poetsbakkery (Practical Joking)}

Learners only recognised part of the word bakkery (baking) and wrote: My ma het ' $n$ koek gebak. Dit was baie lekker. (My mother baked a cake. It was very tasty.)

In a recent examination paper students in the "Culture in Literature" section were asked to compare courtship in Western and African cultures. One student interpreted the word "court" as having the legal meaning.

From these examples it can be seen that problems are caused by a lack of vocabulary and dictionary usage.

\section{(c) Teaching poetry}

A number of teachers lack the knowledge of suitable procedures of teaching poetry correctly. If a poem, for example, refers to an animal such as a cow, they assume the poem deals with the advantages that can be derived from a cow, i.e. use it for obtaining milk, for ploughing, for paying lobola, etc. In Tswana, the poem "Malenkhu a Marumo" by P. Leseyane compares the problems brought about by owning or not owning cattle. If you do own some, you do not sleep because other groups attack you or wild animals hunt the cattle. If you do not own any, you will never be in a position to get married, because you will be unable to pay lobola.

This reflects on the teaching approach of reciting poems using actions without understanding the meaning of the poems. This point is emphasised by Wästberg (1968: 10) who states: "A poem's overall success is equally dependent on the writing and translation of the author as well as the interpretation of the reader through his or her knowledge of the subject matter." Many traditional poems have a high percentage of "difficult" vocabulary. Teachers neglect to use a dictionary to look up these words, and if they do, the words often do not appear in the dictionaries available in the African languages. Most second language speakers who are given literature in the African languages to read are frustrated that they do not find the meaning of many of the words that appear in the text. Lecturers end up by advising them to ask other mother-tongue speakers for the meanings, or otherwise lecturers must waste time explaining the words.

From the above examples it can be deduced that the traditional or rote learning method is to a great extent responsible for the problems experienced. This method does not encourage the use of dictionaries. Rumboll et al. (1988) in the foreword to English in Context Grade 5 states:

The reading, understanding and comprehending Text's sections sets out to move beyond the traditional practice of simply close reading the material for its supposed ultimate meaning, to goal-orientated creative interaction with written, spoken and visual texts. The exercises are designed to improve comprehension (approaching the texts at an informal, concrete level and responding at a more abstract, formal level). 
While creative self-expression is encouraged in the sections on writing, talking, and listening, the primary intention there is to develop and refine the skills of clear, effective communication. The material on the use of dictionaries and other reference works deals with a further essential yet often neglected aspect of language skills acquisition.

The English in Context series is the only series of prescribed text books in which the use of dictionaries are encouraged. Most text books in the African languages do not.

\subsection{Problems Related to Outcomes Based Education (OBE)}

Although Outcomes Based Education (OBE) offers a greater scope for the use of dictionaries, this is not always realized as teachers are often unprepared for implementing the syllabi to the full. Teachers encourage learning from the known to the unknown, but they neglect or ignore what learners already know, i.e. using the functional approach as a basis or link as is the case with the outcomes approach. For example, after presenting a lesson on adjectives according to the functional way of the deductive and inductive approach, the facilitator can then consider what learners could do should they leave school immediately after the lesson on adjectives. Keeping in mind that they can differentiate things/people through colour, size/shape and numbers, the facilitator can then inform them about the different careers they can follow based on a lesson on adjectives. For example: interior decorating, dressmaking, art, make-up art, etc. All these careers need knowledge of and experience in colour, size/shape and numbers.

The five Compulsory Phase Organisers that have been introduced are:

- Personal development and empowerment,

- Communication,

- Environment,

- Culture and society, and

- Economy and development.

All eight Learning Areas therefore have the same themes. This means that each Phase Organiser could have about fifteen programmes which will be impossible to cover in one year. It is important that all facilitators of different Learning Areas should plan together to avoid overlapping of topics and confusing learners. For example, in Economy and Development, one of the Programmes is learning about a bank. A Language, Literacy and Communication (LLC) teacher can teach a text about being mugged or robbed while at the bank. Some terminology about the bank will be introduced, but the focus will be on language teaching. The Economic Management Sciences (EMS) teacher on the other hand, will teach all aspects of the banking system and management, bonds, 
savings accounts, current accounts, loans etc. When assignments of different teachers overlap, it shows that proper lesson planning has been neglected. There prevails much uncertainty among teachers which, for instance, results in the following:

- Some teachers copy the Specific Outcomes and use all of them for writing any programme. Not all Specific Outcomes will be relevant for every topic.

- Being unable to do the application, facilitators sometimes rote learn the theory on outcomes. This could easily encourage teachers to resort to what they are familiar with - using a second language approach in the teaching of a first language.

\section{Problems of Dictionary Use}

\subsection{Lack of the Availability of Dictionaries}

The government does not supply dictionaries, encyclopaedias (which do not exist in the African languages) and informative materials to schools, nor does it even subsidise the acquiring of these materials to foster proper learning.

Some schools do not even have libraries where reading is encouraged, let alone dictionaries with the help of which user skills can be taught. If there is a library, the question to be asked is: How many dictionaries and types of dictionaries plus encyclopaedias should be kept in the library?

Some teachers/facilitators do not have dictionaries in the classroom. The dictionaries found in class, if any, are for the teacher's/facilitator's personal use when studying — not to encourage learners to use them.

Some parents concentrate on buying study materials other than dictionaries, especially dictionaries for the African languages. English dictionaries in private schools, especially previously White schools, are part of the study materials, but not dictionaries in the African languages.

\subsubsection{Lack of a Dictionary Culture}

Through all eleven years of schooling, no dictionaries are used in class. Learners come into contact with dictionaries only at Matriculation level and then usually only as a result of reading Shakespeare where they encounter difficult words. In African languages, even the issues of the series Terminology and Orthographies are not made available or compulsory to learners. Some teachers are even unaware of these publications.

In most of the model lessons from Grades 3-6 the use of dictionaries is not encouraged. Teachers normally write out the difficult words from a text and explain them.

Some teachers are not skilled to do critical analysis in literature, which 
requires a broad knowledge of words, their meanings and effect in order to interpret a text. These teachers are less likely to encourage learners to use dictionaries.

Many words learners encounter in their reading are not included in dictionaries available in the African languages, and these also do not give other essential information such as tonal stress marks for pronunciation. Deficiencies like these may easily cause learners to lose interest in using dictionaries.

At the beginning of every dictionary there are specific notes informing the user how to employ the dictionary. Before trying to find the meanings of words, the learner or teacher should first read and master this section thoroughly. So far, no lesson or course showing learners and teachers how to decode this section has been introduced. Most activities encourage arranging words in alphabetical order only.

In an attempt to encourage the use of dictionaries, one of the OBE publications encourages learners to build databanks with words from the dictionary. This is not a suitable method of teaching dictionary usage. Instead of building a databank of words from a text such as a story they are studying in class, learners randomly select words they do not know. However, if the text they are studying has words, which do not appear in the specific dictionary used, teachers will still have to explain the words with the result that learners will still not often use a dictionary.

Another popular feature in OBE publications is puzzles. Learners are given instructions to fill in the puzzles, which makes it possible for them to work with words. However, in the instructions or in the teacher's guide, no mention is made of asking or encouraging learners to use a dictionary while trying to do the puzzle.

\subsubsection{Suggestions for Establishing a Dictionary Culture}

PanSALB has established dictionary units for all the official South African languages. The units face the challenge of producing dictionaries urgently needed, especially picture dictionaries for Grades R-3 in the African languages. If learners are taught how to use dictionaries in these classes, an ongoing use of dictionaries will be effected.

Each grade should have a dictionary suitable for its level of education. This will not be a problem because the syllabus is structured in such a way that the same themes/programmes can be taught in the Five Compulsory Phase Organisers.

Workshops for teachers should be encouraged in which they are taught strategies of incorporating the use of dictionaries into learners' activities. These may include the following:

- In every grade, a period should be set aside for teaching learners how to use a dictionary and how to use the front matter, interpret the signs, abbreviations, explanations, etc. 
- Before the reading period in school, learners should read a chapter of a prescribed book at home to give them an opportunity to use a dictionary. Reading a prescribed book in class with learners in the higher grades, like Grades 9-12, should be avoided.

- There is a tendency to play word games without emphasising the usage of words in context. If there are dictionaries in the classroom, learners should be encouraged to look up the meanings of words.

Many of today's children are computer-literate and could use on-line dictionaries effectively, provided the teacher is also competent to give the necessary guidance.

\section{Conclusion}

There is no perfect method of teaching, which is a very complex activity. In most cases, the method used in a lesson will be determined by different situations, the type of subject being taught, the resources, time and the type of teacher and learner. The culture of using dictionaries will also be determined by these situations. Teachers can play an important role in enhancing dictionary use in class if they know how to incorporate it in their teaching. However, without good African language dictionaries that are revised on a regular basis, learners will continue compiling lists of words in the classroom without knowing the importance of having a good dictionary and knowing how to use it. Teachers need to be the ones who do the lesson presentations in the form of micro-teaching lessons where different methods of teaching may be explored and evaluated. However, if the workshop presenter does all the talking, giving his/her examples only, rote learning will still be encouraged.

\section{Bibliography}

Afolayan, A. 1999. The Alienated Role of the Mother Tongue Literacy Education in Sustainable National Development: The Western Nigerian Yoruba Example. Paper presented at a Reading for All: Pan African Strategies Conference organised by the Department of Education, Pretoria, Republic of South Africa, 6-9 August 1999.

Ausebel, D.P. 19782. Educational Psychology: A Cognitive View. New York: Holt, Rinehart and Winston.

Goodman, K. 1986. What's Whole in Whole Language? Portsmouth: Heinemann.

Gravett, S. 2001. Adult Learning: Designing and Implementing Learning Events - Dialogic Approach. Pretoria: Van Schaik.

Malimabe, R.M. 1990. The Influence of Non-Standard Varieties on the Standard Setswana of High School Pupils. Unpublished M.A. Dissertation. Johannesburg: Rand Afrikaans University.

Malimabe, R.M. 1997. Subject Didactics: Northern Sotho, Southern Sotho, Tswana. Pretoria: University of South Africa Press. 
Marambana, N.R. 1987. A Decade of Crisis in Black Education, 1976-1986. Unpublished M.Ed. Dissertation. Sovenga: University of the North.

Rumboll, F.C.H. et al. 1988. English in Context Grade 5. Cape Town: Maskew Miller Longman.

Sand, S. and R. Forthering. 1999. Teaching in Adult Basic Education (ABE). Pietermaritzburg: University of Natal Press.

Snyman, J.W. et al. 1996. The Current Position of Setswana in the Republic of South Africa. Legère, K. (Ed.). 1996. Cross-Border Languages. Okahandja: Gamsberg Macmillan.

South African Government. 1997. White Paper on Outcomes Based Education. Pretoria: Government Printer.

Wästberg, Per (Ed.). 1968. The Writer in Modern Africa. Uppsala: The Scandinavian Institute of African Studies. 